\title{
PEMANFAATAN BUNGKIL INTI SAWIT SEBAGAI MEDIA PERTUMBUHAN CACING SUTRA (Tubifex sp.)
}

\author{
Berta Putri*1, Siti Hudaidah, dan Widi Indra Kesuma*2 \\ DOI: http://dx.doi.org/10.23960/jrtbp.v6i2.p729-738
}

\begin{abstract}
The purpose of this research was to observe the effect of fermented palm kernel cake as a growth media for Tubifex sp. This research was conducted at the Aquaculture Laboratory, University of Lampung for 50 days. Completely Randomized Design (CDR) with 5 treatments and 3 replicates design is used for this experiment. The treatments are 100\% field mud, 25\% palm kernel cake $: 75 \%$ field mud, 50\% palm kernel cake : $50 \%$ field mud, $75 \%$ palm kernel cake : $25 \%$ field mud, and 100\% palm kernel cake. The data were analyzed with analysis of variance (ANOVA) continued with Least Significant Difference (LSD) test. The main parameters measured were Tubifex sp population and biomass as well as water quality parameters: $\mathrm{pH}$, temperature, dissolved oxygen, and ammonia. The results showed that fermented palm kernel cake significantly $(p<0,05)$ increase silk worm biomass and population. The best result of this research was found in 50\% fermented palm kernel cake and 50\% field mud media producing $111.008 \mathrm{ind} / \mathrm{m}^{2}$ and $750,72 \mathrm{gr} / \mathrm{m}^{2}$ of Tubifex $\mathrm{sp}$. Water quality during Tubifex sp were measured at 0,26-0,91 mg/l ammonia, $p H$ 6,14-7,11, temperature $25-28^{\circ} \mathrm{C}$, and dissolved oxygen 2,9-3,9 $\mathrm{mg} / \mathrm{l}$.
\end{abstract}

Keywords: Biomass, Fermentation, Palm kernel cake, Population, Tubifex sp.

\section{Pendahuluan}

Tubifex sp. (cacing sutra) merupakan pakan alami bagi larva ikan yang mudah dicerna dengan kandungan nutrisi berupa protein kasar 64,47\%, lemak kasar 17,63\%, abu $7,84 \%$, BETN $10,06 \%$, dan kadar air $11,21 \%$ (Wijayanti, 2010). Selain itu, gerakan aktif Tubifex sp. dapat merangsang larva ikan untuk memakannya (Djarijah, 1995).

Ketersediaan cacing sutra perlu dijaga agar konstan, sehingga perlu dilakukan kultur dengan penambahan nutrisi sebagai makanannya. Media budidaya memegang peranan yang sangat penting terhadap keberhasilan budidaya cacing sutra. Cacing sutra membutuhkan media yang mengandung bahan organik dan bahan anorganik.

Bungkil inti sawit adalah limbah ikutan proses ekstraksi inti sawit. Bungkil inti sawit memiliki kandungan zat-zat makanan yaitu protein kasar 15,40 \%, lemak kasar $6,49 \%$, serat kasar 19,62 \%, Ca 0, 56

\footnotetext{
${ }^{1}$ E-mail: berta.putri@fp.unila.ac.id

2 Jurusan Perikanan dan kelautan, Fakultas Pertanian, Universitas Lampung Jl. Prof. S. Brodjonegoro No.1 Gedong Meneng Bandar Lampung 35145
} 
$\%, \quad \mathrm{P} 0,64 \%$, dengan energi metabolis $2446 \mathrm{kkal} / \mathrm{kg}$ (Noferdiman, 2011). Limbah pengolahan sawit berpotensi sebagai media pertumbuhan cacing sutra karena kandungan bahan organik yang cukup tinggi namun belum termanfaatkan. Hal demikian disebabkan karena bungkil inti sawit memiliki keterbatasan yaitu kandungan serat kasar yang cukup tinggi (terutama lignin), serta tingkat kecernaan rendah (Sofyan, 2007).

Upaya mengatasi bungkil inti sawit yang memiliki kandungan serat kasar dapat dilakukan dengan cara fermentasi.

Bungkil inti sawit yang telah difermentasi memiliki kandungan nutrisi tinggi. Nutrisi tersebut diharapkan dapat digunakan sebagai alternatif bahan dalam pembuatan media untuk meningkatkan pertumbuhan dalam budidaya cacing sutra.

Tujuan dari penelitian ini adalah untuk mengetahui pengaruh penggunaan media fermentasi bungkil inti sawit terhadap pertumbuhan biomassa dan populasi cacing sutra (Tubifex sp.).

\section{Metode}

Penelitian ini menggunakan Rancangan Acak Lengkap (RAL) yang terdiri atas formulasi media (substrat) lumpur sawah dan bungkil inti sawit dengan lima perlakuan tiga ulangan. Perlakuan yang digunakan yaitu :

$\mathrm{A}=$ media $0 \%$ (bungkil inti sawit) : $100 \%$ (lumpur sawah)

$\mathrm{B}=$ media $25 \%$ (bungkil inti sawit) : $75 \%$ (lumpur sawah)
$\mathrm{C}=$ media $50 \%$ (bungkil inti sawit) $50 \%$ (lumpur sawah)

$\mathrm{D}=$ media $75 \%$ (bungkil inti sawit) : $25 \%$ (lumpur sawah)

$\mathrm{E}=$ media $100 \%$ (bungkil inti sawit) :0\% (lumpur sawah)

\section{Alat}

Peralatan yang digunakan dalam penelitian ini yaitu: kotak kayu ukuran $50 \times 15 \times 10 \mathrm{~cm}$, terpal plastik, pompa air, pipa paralon diameter 2,5 $\mathrm{cm}$, selang, gelas ukur, pipet tetes, tabung reaksi $10 \mathrm{ml}$, labu erlenmeyer $100 \mathrm{ml}$, spektrofotometer, saringan, ember, baskom, fillter, termometer, $\mathrm{pH}$ meter, DO meter, hand counter, dan timbangan digital.

\section{Bahan}

Bahan-bahan yang digunakan untuk penelitian ini adalah air bersih, mikroorganisme fermentasi, gula merah, lumpur sawah, bungkil inti sawit, dan cacing sutra.

\section{Prosedur}

Penelitian ini dilakukan dalam lima tahap yakni:

a. Persiapan wadah.

Wadah yang digunakan adalah

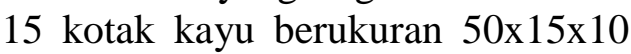
$\mathrm{cm}$ yang dilapisi terpal. Sedangkan wadah fillter berupa tabung fiber plastik yang berisi busa fillter, ijuk, arang, dan batu zeolit. Bagian ujung pipa yang berada dalam tangki disambungkan dengan pompa untuk menyedot air naik ke wadah pemeliharaan, air dialirkan dengan prinsip resirkulasi.

b. Persiapan media hidup cacing sutra.

Bungkil inti sawit sebanyak 30 $\mathrm{kg}$ difermentasi dengan cara mencampur air sebanyak $20.000 \mathrm{ml}$ 
air, $200 \mathrm{ml}$ larutan gula merah, dan $200 \mathrm{ml}$ mikroorganisme fermenter (Rahmadi et al, 2014). Bahan yang telah tercampur tersebut kemudian dimasukkan dalam wadah tertutup lalu didiamkan terfermentasi selama 40 hari. Pengukuran kadar C-organik dari bungkil inti sawit dilakukan sebelum dan setelah fermentasi. Selanjutnya, pembuatan formulasi media hidup cacing sutra sesuai dengan perlakuan. Setelah media perlakuan tercampur rata, dialiri air dengan debit $300 \mathrm{ml} /$ menit (Shafrudin et al, 2005) selama 30 hari.

c. Pemeliharaan cacing sutra.

Cacing sutra ditebar dengan padat penebaran $220 \mathrm{gr} / \mathrm{m}^{2}$ (Johari, 2012). Kualitas air wadah pemeliharaan dijaga sehingga selalu optimal dengan sistem air mengalir (resirkulasi). Parameter lingkungan yang diamati pada penelitian ini adalah $\mathrm{pH}$, kadar oksigen, amoniak, dan suhu.

d. Sampling.

Sampling dilakukan pada hari ke10, ke-20, ke-30, ke-40, dan ke-50. Sampling dilakukan dengan cara memasukkan pipa paralon berdiameter $3 \mathrm{~cm}$ ke dalam substrat sampai ke dasar wadah pada bagian inlet, tengah, dan outlet wadah. Kemudian, lubang bagian atas ditutup lalu paralon diangkat. Cacing yang diperoleh dibilas dengan air menggunakan saringan. Cacing dipisahkan dari subtrat dengan cara mengguncang saringan. Cara ini dilakukan berulang kali hingga cacing dan substrat terpisah, sehingga diperoleh cacing yang akan ditimbang.

e. Pemanenan.

Cacing sutra dipanen setelah 50 hari masa pemeliharaan. Panen cacing sutra dilakukan dengan menyaring media menggunakan saringan halus pada aliran air. Hasil saringan berupa cacing dan substrat kasar didiamkan dalam wadah dan ditutup menggunakan plastik hitam selama 3 jam. Penutupan dilakukan supaya cacing naik ke atas permukan serta mempermudah untuk proses pemisahan (Findi, 2011). Cacing yang sudah didapat lalu dibilas dengan air hingga bersih dari lumpur halus lalu ditimbang menggunakan timbangan.

Parameter yang diukur selama penelitian adalah pertumbuhan biomassa dan populasi. Biomassa dihitung dengan rumus (Effendie, 1997):

$$
\mathrm{Wm}=\mathrm{Wt}-\mathrm{Wo}
$$

Ket: Wm : Pertumbuhan mutlak (gr) $\mathrm{Wt}$ : rerata berat akhir (gr) Wo : rerata berat awal (gr)

Sedangkan populasi dihitung dengan rumus:

$$
\text { Populasi }=\sum \mathrm{n} \times \frac{\mathrm{L}}{\mathrm{l}}
$$

Ket: $\sum \mathrm{n}$ :Jumlah rata-rata individu

L : Luas wadah budidaya $\left(\mathrm{m}^{2}\right)$

1 :Luas wadah sampel $\left(\mathrm{m}^{2}\right)$

\section{Hasil dan Pembahasan}

Proses fermentasi bungkil inti sawit dilakukan sebelum digunakan sebagai media budidaya Tubifex sp. Fermentasi dilakukan selama 40 hari dan mendapatkan hasil nilai $\mathrm{C}$ organik turun sedangkan nilai $\mathrm{N}$ Organik mengalami peningkatan. 
Tabel 1. Kandungan C-Organik dan N-Organik Bungkil Inti Sawit Sebelum dan Setelah Fermentasi

\begin{tabular}{lccc}
\hline \multicolumn{1}{c}{ Sampel } & C-Organik (\%) & N-Organik (\%) & C/N ratio \\
\hline Bungkil sebelum fermentasi & 49,29 & 2,64 & 18,67 \\
Bungkil setelah fermentasi & 42,86 & 2,79 & 15,36 \\
\hline
\end{tabular}

Proses fermentasi menyebabkan kandungan C-Organik pada suatu bahan menurun karena bakteri menggunakan sebagian unsur karbon yang ada dalam bahan sebagai sumber nutrisi untuk berkembang biak selama proses fermentasi. Sedangkan kandungan N-organik setelah fermentasi mengalami peningkatan karena fermentasi dapat melepaskan unsur hara $\mathrm{N}$ yang berasal dari perombakan ammonium oleh bakteri (Surya dan Suyono, 2013).

Tabel 2. Kandungan C-Organik dan N-Organik Media Budidaya Tubifex sp.

\begin{tabular}{cccc}
\hline Perlakuan & C-Organik (\%) & N-Organik (\%) & C/N ratio \\
\hline A & 3.65 & 0.3 & 12.16 \\
B & 15.27 & 0.71 & 21.50 \\
C & 18.59 & 1.01 & 18.40 \\
D & 38.51 & 2.05 & 18.78 \\
E & 42.86 & 2.79 & 15.36 \\
\hline
\end{tabular}

Persentase nilai C dan N-Organik pada setiap media budidaya cacing sutra memiliki perbedaan (Tabel 2). Kandungan nilai $\mathrm{C}$ dan $\mathrm{N}$ organik tertinggi terdapat pada perlakuan $\mathrm{E}$ yaitu media $100 \%$ bungkil inti sawit sebesar 42,86\% (C-Organik) dan $2,79 \%$ (N-Organik), sedangkan yang terendah pada perlakuan A yaitu media $100 \%$ lumpur sawah sebesar $3,65 \%$ (C-Organik) dan 0,3\% (NOrganik). Menurut Muria (2012), media dengan rasio $\mathrm{C} / \mathrm{N}$ yang berbeda memiliki pengaruh terhadap pertumbuhan cacing sutra. Nilai $\mathrm{C} / \mathrm{N}$ yang optimal dalam penelitian yaitu pada media $50 \%$ bungkil inti sawit dengan nilai $\mathrm{C} / \mathrm{N}$ ratio sebesar 18,40 .

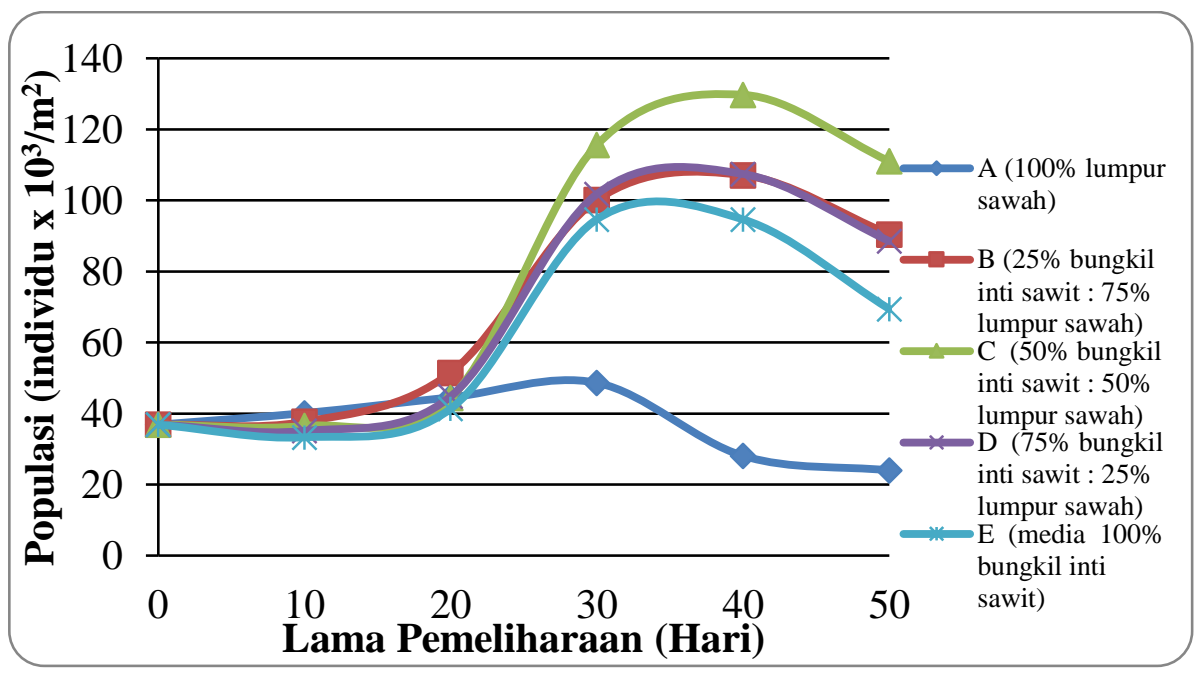

Gambar 1. Populasi Cacing Sutra Selama 50 Hari Pemeliharaan 
Berdasarkan Gambar 1, pertumbuhan populasi cacing sutra mengalami fase adaptasi pada 10 hari pertama, hal ini sama seperti pada penelitian yang dilakukan oleh Ansyari dan Rifai (2005) tentang penggunaan pupuk pelengkap cair (PPC) bioton untuk pertumbuhan cacing sutra yaitu terlihat mengalami penurunan populasi. Populasi cacing sutra terjadi penurunan karena kematian dan belum adanya proses reproduksi. Kemudian populasi cacing sutra mulai meningkat sejak hari ke-10 hingga ke-20. Peningkatan populasi terjadi karena adanya penetasan individu baru. Menurut Nascimento dan Alves (2008), telur cacing sutra mulai menetas dan keluar dari kokon pada hari ke-10 hingga hari ke-20. Pertumbuhan terus meningkat pada hari ke-20 hingga ke30 , dan mengalami fase puncak pada hari ke-40 untuk media $25 \%$ bungkil inti sawit, $50 \%$ bungkil inti sawit, $75 \%$ bungkil inti sawit, $100 \%$ bungkil inti sawit, sedangkan untuk media $100 \%$ lumpur sawah puncak populasi pada hari ke-30. Peningkatan populasi dapat terus terjadi disebabkan oleh ketersediaan makanan yang cukup, sehingga dapat menurunkan tingkat persaingan antara cacing dewasa dan cacing muda untuk memperoleh makanan (Putri et al, 2014). Populasi cacing sutra mengalami penurunan mulai hari ke-40 untuk media $100 \%$ lumpur sawah, sedangkan pada media $25 \%$ bungkil inti sawit, $50 \%$ bungkil inti sawit, $75 \%$ bungkil inti sawit, dan $100 \%$ bungkil inti sawit antara hari ke-40 dan ke-50.

Berdasarkan grafik tersebut dapat diketahui bahwa siklus hidup cacing sutra dalam suatu media terdapat 4 fase yaitu fase adaptasi, fase pertumbuhan $(\log )$, fase stasioner, dan fase kematian (death). Penelitian Febrianti (2004) tentang pengaruh pemupukan harian kotoran ayam terhadap pertumbuhan cacing sutra juga menunjukkan bahwa pertumbuhan populasi puncak cacing sutra terjadi pada hari ke-40 dan terus mengalami penurunan hingga hari ke50. Penurunan populasi terjadi karena persaingan makanan sedangkan makanan yang tersedia tidak mengalami peningkatan. 


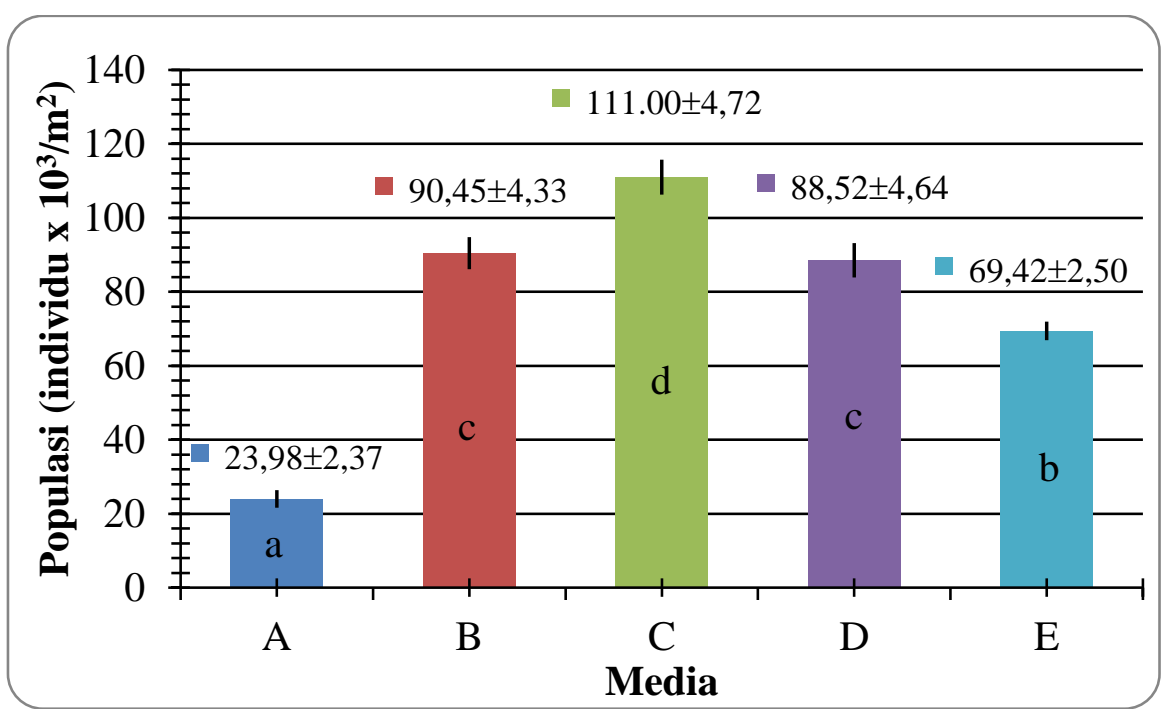

Keterangan: Huruf kecil yang sama pada histogram menunjukkan tidak berbeda nyata pada tingkat kepercayaan $95 \%$.

Gambar 2. Grafik populasi Tubifex sp.

Rerata populasi cacing sutra berdasarkan Gambar 2 menunjukkan pertumbuhan cacing sutra tertinggi diperoleh pada media $50 \%$ bungki inti sawit yaitu sebanyak $111.008 \mathrm{ind} / \mathrm{m}^{2}$, sedangkan populasi terendah terdapat pada media $100 \%$ lumpur sawah sebanyak $23.989 \mathrm{ind} / \mathrm{m}^{2}$. Jumlah populasi dari fekunditas cacing sutra dapat berbeda karena dipengaruhi oleh suhu, aliran air, dan bahan organik yang ada pada media budidaya (Mollah et al., 2012).

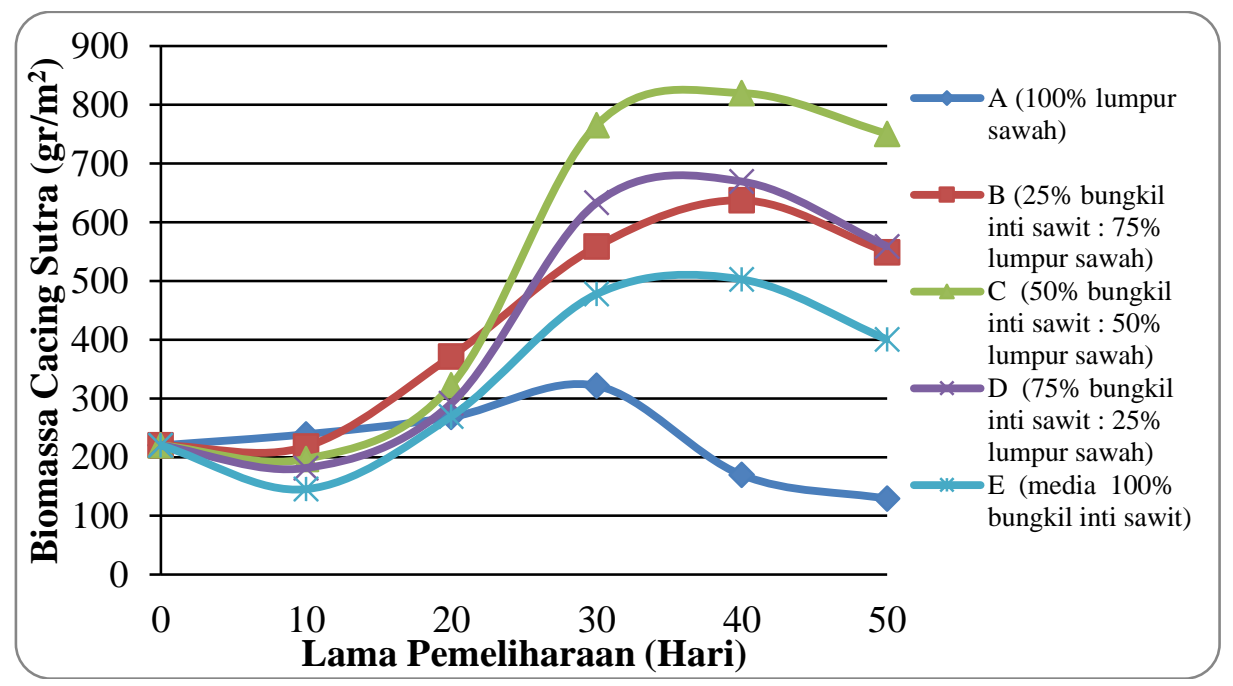

Gambar 3. Biomassa Tubifex sp Selama 50 Hari Pemeliharaan

Hasil penelitian ini menunjukkan pertumbuhan biomassa cacing sutra memiliki pola yang sama dengan pertumbuhan populasinya (Gambar $3)$. 


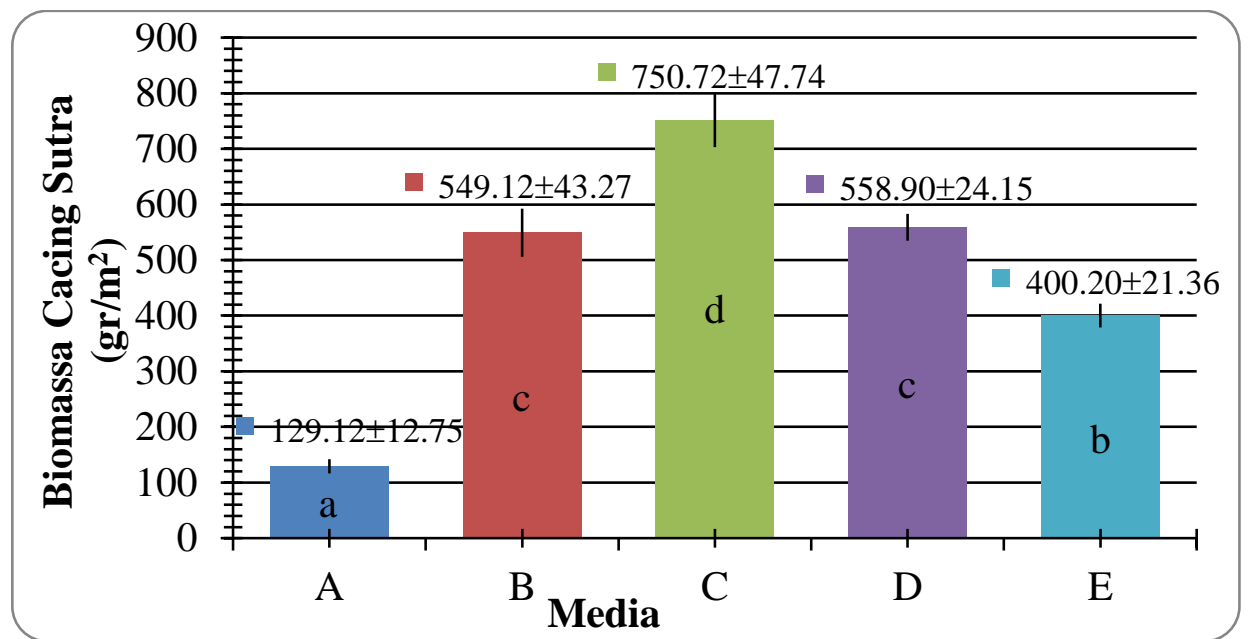

Keterangan: Huruf kecil yang sama pada histogram menunjukkan tidak berbeda nyata pada tingkat kepercayaan $95 \%$.

Gambar 4. Grafik Biomassa Tubifex sp.

Grafik pada gambar 4 menunjukkan bahwa biomassa tertinggi terdapat pada media $50 \%$ bungkil inti sawit yaitu sebesar $750,72 \mathrm{gr} / \mathrm{m}^{2}$, sedangkan biomassa terendah terdapat pada media $100 \%$ lumpur sawah sebesar $129,12 \mathrm{gr} / \mathrm{m}^{2}$.

Hasil analisis statistik dari biomassa dan populasi cacing sutra menunjukkan bahwa perbedaan formulasi media bungkil inti sawit memberikan pengaruh nyata terhadap biomassa cacing sutra $(\mathrm{p}<0,05)$. Selanjutnya dilakukan uji Beda Nyata Terkecil (BNT) untuk mengetahui perbedaan antar perlakuan. Hasil dari uji BNT menunjukkan media 100\% lumpur sawah berbeda nyata dengan media $25 \%$ bungkil inti sawit, 50\% bungkil inti sawit, $75 \%$ bungkil inti sawit, dan $100 \%$ bungkil inti sawit, sedangkan hanya media $25 \%$ bungkil inti sawit yang tidak berbeda nyata dengan media $75 \%$ bungkil inti sawit.

Pertumbuhan biomassa cacing sutra dipengaruhi oleh tersedianya bahan organik yang dapat dimanfaatkan oleh cacing sutra (Pardiansyah et al, 2014). Bahan organik yang masuk dalam media akan mengalami dekomposisi oleh bakteri sehingga dapat diubah menjadi partikel-partikel organik yang dapat dijadikan nutrisi oleh cacing sutera (Febrianti, 2004). Semakin cepat tumbuhnya bakteri maka semakin cepat bahan organik yang terdekomposisi, sehingga katersediaan nutrisi untuk cacing sutra dalam media semakin cepat terbentuk (Nurfitriani, 2014).

Karbon (C) dan nitrogen (N) merupakan unsur pembentuk energi dan protein. Karbon dan nitrogen akan mempengaruhi perkembangan bakteri yang nantinya akan dimanfaatkan sebagai sumber makanan cacing sutra. Hubungan nilai $\mathrm{C}$ dan $\mathrm{N}$ dengan mekanisme kerja bakteri yaitu bakteri memperoleh makanan melalui substrat karbon dan nitrogen sehingga jumlah bakteri dapat meningkat. Menurut Darwati (2013), apabila nilai $\mathrm{C}$ dan $\mathrm{N}$ terlalu tinggi artinya bahan organik masih mengandung fraksifraksi padat. Nilai $\mathrm{C}$ dan $\mathrm{N}$ yang terlalu tinggi akan memperlambat 
proses pembusukan bahan yang dilakukan oleh mikroorganisme sehingga bahan masih berupa serat kasar (Widarti et al, 2015), sehingga akan sulit untuk dapat langsung dimanfaatkan cacing. Oleh karena itu pertumbuhan pada media $75 \%$ bungkil inti sawit dan $100 \%$ bungkil inti sawit yang memiliki nilai $\mathrm{C}$ dan $\mathrm{N}$ tinggi justru memiliki biomassa lebih rendah dari media $50 \%$ bungkil inti sawit yang memiliki nilai $\mathrm{C}$ dan $\mathrm{N}$ yang lebih rendah darimedia tersebut.

Hasil penelitian Sulistiyo et al (2012) mengenai pemanfaatan ulang limbah organik substrat di alam untuk budidaya cacing sutra menyatakan bahwa semakin besar bahan organik yang diberikan tidak memberikan pertumbuhan bobot mutlak yang besar pula.

Media budidaya cacing sutra dengan nilai perbandingan $\mathrm{C} / \mathrm{N}$ yang rendah (Tabel 2) dapat langsung dimanfaatkan oleh mikroorganisme, sehingga mampu menyediakan nutrisi yang cukup untuk pertumbuhan. Namun media yang memiliki nilai perbandingan $\mathrm{C} / \mathrm{N}$ yang terlalu rendah seperti pada media 100\% lumpur sawah juga menghasilkan jumlah pertumbuhan Tubifex sp. yang rendah, dikarenakan jumlah nutrisi yang dibutuhkan oleh cacing sutra untuk tumbuh dan berkembang kurang mencukupi (Chilmawati et al, 2014). Hasil penelitian Safrina et al (2015) yang menggunakan lumpur sawah sebagai media budidaya cacing sutra juga mendapat hasil pertumbuhan rendah yaitu sebesar 6 , $27 \mathrm{gr} / \mathrm{m}^{2}$. Suminto (2014), menyatakan bahwa kandungan protein dan energi dalam pakan harus seimbang karena kekurangan atau kelebihan energi dapat menurunkan tingkat pertumbuhan.

Hasil pengukuran kualitas air media pemeliharaan cacing sutra (Tubifex sp.) selama 50 hari masa pemeliharaan dapat dilihat pada Tabel 3.

Tabel 3. Hasil Pengukuran Kualitas Air Media Budidaya Tubifex sp.

\begin{tabular}{lccccc}
\hline \multicolumn{1}{c}{ Parameter } & \multicolumn{5}{c}{ Perlakuan } \\
\cline { 2 - 6 } Kualitas Air & $\mathbf{A}$ & $\mathbf{B}$ & $\mathbf{C}$ & $\mathbf{D}$ & $\mathbf{E}$ \\
\hline Amoniak (mg/l) & $0,77-0,91$ & $0,61-0,63$ & $0,30-0,67$ & $0,29-0,38$ & $0,26-0,31$ \\
pH & $6,14-7,11$ & $6,56-7,05$ & $6,58-7,05$ & $6,48-7,01$ & $6,38-7,05$ \\
Suhu $\left({ }^{\circ} \mathrm{C}\right)$ & $25-28$ & $25-28$ & $25-28$ & $25-28$ & $25-28$ \\
DO $(\mathrm{mg} / \mathrm{l})$ & $2,9-3,8$ & $3,3-3,7$ & $3,4-3,8$ & $3,3-3,9$ & $3,2-3,9$ \\
\hline
\end{tabular}

\section{Kesimpulan dan Saran}

Penggunaan media dengan formulasi bungkil inti sawit dan lumpur sawah berpengaruh nyata terhadap pertumbuhan populasi dan biomassa cacing sutra. Media budidaya dengan formulasi $50 \%$ bungkil inti sawit dan $50 \%$ lumpur sawah menghasilkan biomasa dan populasi tertinggi.

\section{Daftar Pustaka}

Ansyari, P. dan Rifai, M.A. 2005. Penggunaan Berbagai Dosis Pupuk Pelengkap Cair (PPC) Bioton untuk Pertumbuhan Populasi Cacing Tubifex (Tubifex sp.). Agroscientiae, 12(1): 25-32.

Chilmawati, D., Suminto, dan Yuniarti, T. 2015. Pemanfaatan Fermentasi Limbah Organik Ampas Tahu, Bekatul dan Kotoran 
Ayam untuk Peningkatan Produksi Kultur dan Kualitas Cacing Sutera (Tubifex sp). Jurnal Ilmu Pengetahuan dan Teknologi, 28(2): 186-201

Darwati. 2013. Kandungan Kalium Rasio C/N dan $\mathrm{pH}$ pada Pupuk Cair Hasil Fermentasi Kotoran Berbagai Ternak Menggunakan Starter Starbio. Skripsi. Semarang: Fakultas Pendidikan Matematika dan Ilmu Pengetahuan Alam, IKIP PGRI.

Djarijah, A.S. 1995. Pakan Ikan Alami. Yogyakarta: Kanisius.

Effendie, M.I. 1997. Biologi Perikanan. Yogyakarta: Yayasan Pustaka Nusatama.

Febrianti, D. 2004. Pengaruh Pemupukan Harian dengan Kotoran Ayam terhadap Pertumbuhan Populasi dan Biomassa Cacing Sutra (Limnodrillus). Skripsi. Bogor: Fakultas Perikanan dan Ilmu Kelautan, IPB.

Findi, S. 2011. Pengaruh Tingkat Pemberian Kotoran Sapi terhadap Pertumbuhan Biomassa Cacing Sutra (Tubificidae). Skripsi. Bogor: Program Studi Teknologi dan Manajemen Akuakultur, Fakultas Perikanan dan Ilmu Kelautan, Institut Pertanian Bogor. Johari, Y.T. 2012. Pemanfaatan Limbah Lumpur (sludge) Kelapa Sawit dan Kotoran Sapi untuk Budidaya Cacing Sutra (Tubifex sp) dalam Pengembangan Pakan Alami. Tesis. Jakarta: Program Pascasarjana, Universitas Terbuka. Mollah, M.F.A., Mosharaf, K., dan Mariom. 2012. Selection of Suitable Media and Intervals of Media Inoculation for Culturing
Tubificid Worms. J. Bangladesh Agril. Univ., 10(2): 325-330

Muria, E.S. 2012. Pengaruh Penggunaan Media dengan Rasio $\mathrm{C}: \mathrm{N}$ yang Berbeda terhadap Pertumbuhan Tubifex. Tesis. Surabaya: Universitas Airlangga.

Nascimento, H.L.S dan Alves, R.G. 2008. Cocoon Production and Hatching Rates of Branchiura sowerbyi Beddard (Oligochaeta: Tubificidae). Revista Brasileira de Zoologia, 25(1): 16-19.

Noferdiman. 2011. Penggunaan Bungkil Inti Sawit Fermentasi oleh Jamur Pleurotus ostreatus dalam Ransum terhadap Performans Ayam Broiler. Jurnal Ilmiah Ilmuilmu Peternakan, XIV(1): 35-43.

Nurfitriani, L., Suminto, dan Hutabarat, J. 2014. Pengaruh Penambahan Kotoran Ayam, Ampas Tahu dan Silase Ikan Rucah dalam Media Kultur terhadap Biomassa, Populasi dan Kandungan Nutrisi Cacing Sutera (Tubifex sp.). Journal of Aquaculture Management and Technology, III(4): 109-117.

Pardiansyah, D., Supriyono, E., dan Djokosetiyanto, D. 2014. Evaluasi Budidaya Cacing Sutra yang Terintegrasi dengan Budidaya Ikan Lele Sistem Bioflok. Jurnal Akuakultur Indonesia 13(1): 2835.

Putri, D.S., Supriyono, E., dan Djokosetiyanto, D. 2014. Pemanfaatan Kotoran Ayam Fermentasi dan Limbah Budidaya Lele pada Budidaya Cacing Sutra dengan Sistem Resirkulasi. Jurnal Akuakultur Indonesia, 13(2): 132139.

Rahmadi, R., Awaludin, A., dan Itnawita. 2014. Pemanfaatan 
Limbah Padat Tandan Kosong Kelapa Sawit dan Tanaman PakisPakisan untuk Prodeksi Kompos Memnggunakan Aktivator EM-4. JOM FMIPA Binawidya. Pekanbaru, 1(2): 245-253.

Safrina. 2015. Pertumbuhan Cacing Sutra (Tubifex sp) yang Dipelihara pada Media Kulita Pisang Kepok (Musa parasisiaca) dan Lumpur Sawah. Skripsi. Bandar Lampung: Fakultas Pertanian, Universitas Lampung.

Shafrudin, D., Efiyanti, W., dan Widanarni. 2005. Pemanfaatan Ulang Limbah Organik dari Substrat Tubifex sp. di Alam. Jurnal Akuakultur Indonesia, 4 (2): 97-102.

Sofyan, L.A., Ramli, N., Wiryawan, K.G., Zarkasie, K., dan Piliang, W.G. 2007. Polisakarida Mengandung Mannan dari Bungkil Inti Sawit sebagai Anti Mikroba Salmonella Thypimurium pada Ayam. Journal of Animal Science and Technology, 30(2): 139-146.

Sulistiyo, A., Widiastuti, I. M., dan Rizal, A. 2012. Pemanfaatan Ulang Limbah Organik dari Substrat Tubifex sp. di Alam untuk Pertumbuhan Bobot Tubifex sp. Jurnal Agrisains, 13(3): 233-238.

Suminto, M. dan Hutabarat, J. 2014. Pengaruh Penambahan Kotoran Ayam, Silase Ikan Rucah dan Tepung Tapioka dalam Media Kultur terhadap Biomassa, Populasi dan Kandungan Nutrisi Cacing Sutera (Tubifex sp.). Journal of Aquaculture Management and Technology, 3(4): 151-157.

Surya, R.E. dan Suyono. 2013. Pengaruh Pengomposan terhadap
Rasio C/N Kotoran Ayam dan Kadar Hara NPK tersedia serta Kapasitas Tukar Kation Tanah. UNESA Journal of Chemistry, II(1): 137-144.

Widarti, B.N., Wardhini, W.K., dan Sarwono, E. 2015. Pengaruh Rasio $\mathrm{C} / \mathrm{N}$ Bahan Baku pada Pembuatan Kompos dari Kubis dan Kulit Pisang. Jurnal Integrasi Proses, 5(2): 75-80.

Wijayanti, K. 2010. Pengaruh Pemberian Pakan Alami yang Berbeda terhadap Sintasan dan Pertumbuhan Benih Ikan Palmas (Polypterus senegalus senegalus Cuvier, 1829). Skripsi. Depok: Departemen Biologi Akuakultur, Fakultas Matematika dan Ilmu Pengetahuan Alam, Universitas Indonesia. 